\title{
Empirical Research of the Maintenance Time of Foreign Patents without the Foreign Priority Granted by USA, Korea, Japan and China
}

\author{
Yongzhong Qiao ${ }^{a}$, Yan Sun \\ Intellectual Property Research Institute, Xiamen University, Xiamen, 361005, P.R.China

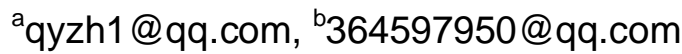

\begin{abstract}
Keywords: foreign patent; patent maintenance time; foreign priority
Abstract: The foreign priority is close related with the foreign patent. For foreign patents, the number of patents with foreign priority is far more than that of the patents without foreign priority. Because of the different innovation abilities and the unbalanced intellectual property development, the average maintenance time of foreign patents without the foreign priority is shorter than that of the patents with the foreign priority granted by USA, Korea and Japan, while the average maintenance time of patents without the foreign priority is longer than that of the patents with the foreign priority granted by China.
\end{abstract}

\section{Introduction}

The patent ${ }^{1}$ priority right is a time-limited right, allowing the claimant to file a subsequent applicant for the same invention as of the date of filing the first application of patent within a certain period of time. It includes the foreign priority and the domestic priority. There are many differences in the periods and limits of priority of the domestic priority systems in USA, China, Japan and Korea, while the foreign priority systems of patent systems in many member countries of PCT are similar. So the foreign priority system only was discussed in this paper. In these four countries, the foreign priority systems are established with the multilateral arrangement, the bilateral agreement and the relationship of mutual benefit. It means the claimant can files a subsequent applicant in another country for the same invention as of the date of filing the first application within 12 months.

A claimant of foreign priority usually files the first application of a patent at home country, then files the subsequent application of this patent in other countries within the period of priority. It means that most foreign patents could file foreign priority rights. However, a few of foreign patents have no foreign priority right, which means they firstly file the applications of patent in foreign countries. Maybe there are two reasons of this phenomenon. One is that claimants are fail to firstly file the formal applications of patents at home country because their patent application were withdrawn, abandoned or rejected, and the inventions are still unknown to be opened; the other is that claimants give up their first application of patent at home country by themselves, for example, the multinational company has a invention whose market in a foreign country, they would to give up the patent application at home country for saving money and filing the patent application in foreign country firstly.

Literature review shows that researches of patent maintenance focus on three parts. The first is the research on the length of patent maintenance time, for example, Zeebroeck found European patent granted rate was gradually slow down but the maintenance time become longer during 1980 to 2000 . [1] The second is the research on the affecting factors of patent maintenance time, for example, Scotchmer thought that the patent annual fee balances the patent maintenance cost and the patent maintenance profit; ${ }^{[2]} \mathrm{Wu}$ Hong, Fu Xiuying and Dong Kun compared domestic patent and Japanese patent granted by China in fuel cell field, and found that the macro factors of patents maintenance time doesn't absolutely influence a single technical field patent maintenance time. ${ }^{[3]}$ The last is the research on the relationship between the patent maintenance time and the patent quality, for example, Schankerman and Pakes thought the better the patent quality is, the longer the maintenance time is; ${ }^{[4]}$ Zhu Xuezhong found that the average maintenance time of patents granted by China is shorter, which reflects the patent quality is inferior based on the maintenance time of patents granted by China. ${ }^{[5]}$ 
The researches on the foreign priority focus on two parts. One is from the practical view, for example, Eike Ullmann thought that a legitimate perception of right from priority must consider the interests of the patent applicant as well as the interest of the general public at same time. ${ }^{[6]}$ The other is from theoretical view, for example, Du Juan thought that the foreign priority is a right that independent from the patent application right in essence and its transfer has economic value in some situations. ${ }^{\text {[7] }}$

The basic purpose of the priority right is to safeguard, for a limited period, the interests of a patent applicant in his endeavor to obtain international protections for his invention, thereby alleviating the negative consequences of the principle of territoriality in patent law. ${ }^{[8]}$ In the period of priority, claimant can fully consider whether file a patent application in another country based on the cost of application and maintenance, or improve their inventions. From this perspective, we believe that the values and the maintenance time of foreign patents with foreign priority are higher and longer than that of patents without foreign priority. We try to compare the distributions of maintenance time of foreign patents without priorities in order to find the difference between the foreign patents without foreign priority and the foreign patents with foreign priority, based on the maintenance information of patents granted by USA, Korea, Japan and China.

\section{Data Sources}

The reason why choose the patents granted in 1994 is that it is a complete cycle of patent maintenance from 1994 to 2014. It can reflect developing trend of patents maintenance time. 3838 patents granted in 1994 by China were choosing from the patent search platform on the website of State Intellectual Property Office of the P.R.C (SIPO) (ending on December 31, 2014). Based on this patent information to established "the information database of patents granted by China in 1994". Chinese patent information database's size is smallest of the four countries, so we take 3838 patents as other three countries' database size. "information database of the patents granted by USA in 1994", "information database of the patents granted by Korea in 1994" and "information database of the patents granted by Japan in 1994" were established by the systematic method from patent search platforms of United States Patent and Trademark Office's website, Korean Intellectual Property Office's website and Japan patent office's website. The above four databases are the analysis basis in this paper.

\section{Data Analysis}

\section{The distribution of foreign patents without the foreign priority}

The quantitative distribution of foreign patents without the foreign priority. The quantity distributions of foreign patents without the foreign priority granted by USA, Korea, Japan and China are shown in table 1 . Table 1 shows that the number of the foreign patents without the foreign priority granted in USA, China, Korea and Japan are 237 patents, 183 patents, 91 patents, 46 patents respectively, accounting for $6.18 \%, 4.77 \%, 2.37 \%, 1.20 \%$ of the total sample respectively. The number of granted patents without the foreign priority in Japan is more than that of granted patents without the foreign priority in USA and Korean, and the number of granted patents without the foreign priority in China is least. The number of foreign patents without the foreign priority granted by China account for the highest percentage of the total patents without the foreign priority (10.26\%); the percentage of the granted patents without the foreign priority in USA and Korea accounting for the all sample are $10.15 \%$ and $4.68 \%$ respectively. However, the percentage of the granted patents without the foreign priority in Japan accounting for the all sample only is $1.34 \%$. From the perspective of the sorts of foreign or domestic patents, the quantities of foreign patents granted by China, Korea, USA and Japan decreases gradually. What's more, only 394 foreign patents were granted by Japan in 1994, and this number of foreign patent is far less than that of other three countries. This is reason that the ratio of foreign patents without the foreign priority granted by Japan is higher than that of patents granted by China and Korea. In a word, the quantities of foreign patents without the foreign priority are smaller in four countries. 
Table 1 Quantitative distribution of foreign patents without the foreign priority

\begin{tabular}{ccccccc}
\hline & $\begin{array}{l}\text { Foreign patents without } \\
\text { the foreign priority }\end{array}$ & Sample patents & \multicolumn{2}{l}{$\begin{array}{l}\text { Patents without the } \\
\text { foreign priority }\end{array}$} & Foreign patents \\
\hline US & 237 & $6.18 \%$ & 2335 & $10.15 \%$ & 1676 & $14.14 \%$ \\
KR & 91 & $2.37 \%$ & 1946 & $4.68 \%$ & 1934 & $4.71 \%$ \\
JP & 46 & $1.20 \%$ & 3423 & $1.34 \%$ & 394 & $11.66 \%$ \\
CN & 183 & $4.77 \%$ & 1784 & $10.26 \%$ & 2224 & $8.23 \%$ \\
\hline
\end{tabular}

Note: percentage=foreign patents without foreign priority's quantity / the kind of patents' quantity.

The distribution of technological fields of foreign patents without the foreign priority. Figure 1 shows the distributions of technological fields of foreign patents without the foreign priority in four countries. The foreign patents without foreign priority granted in USA, Korea and China are mainly distributed in field A (Agriculture), field B (Performing Operations and Transporting) and field C (Chemistry and Metallurgy). What's more, in field A (Agriculture), USA has the most patents (60 patents); China has 30 patents followed and Korea has the least, only 13 patents. In field B (Performing Operations and Transporting), USA, China and Korea have 58 patents, 48 patents and 20 patents respectively. In field C (Chemistry and Metallurgy), China has 59 patents which is far more than USA and Korea. While the distribution of technological fields of those patents granted in Japan are little different from above three countries, which is mainly distributed in field C (Chemistry, Metallurgy), field $\mathrm{G}$ (Physics), field $\mathrm{H}$ (Electricity) and field $\mathrm{B}$ (Performing Operations, Transporting). Even though those patents granted by Japan are mainly distributed in these three fields, the number of patents in these three fields are still less than other three countries, only are 11 patents, 11 patents, 8 patents and 8 patents respectively. Meanwhile, the four countries have same place that all of their patents are least distributed in field D (Textiles, Paper) and field E (Fixed Constructions). We could find that most of patents are distributed in the technological fields of A (Agriculture), B (Performing Operations and Transporting) and C (Chemistry and Metallurgy), while few patents numbers are distributed in the technological fields of D (Textiles and Paper) and E (Fixed Constructions) in four countries.

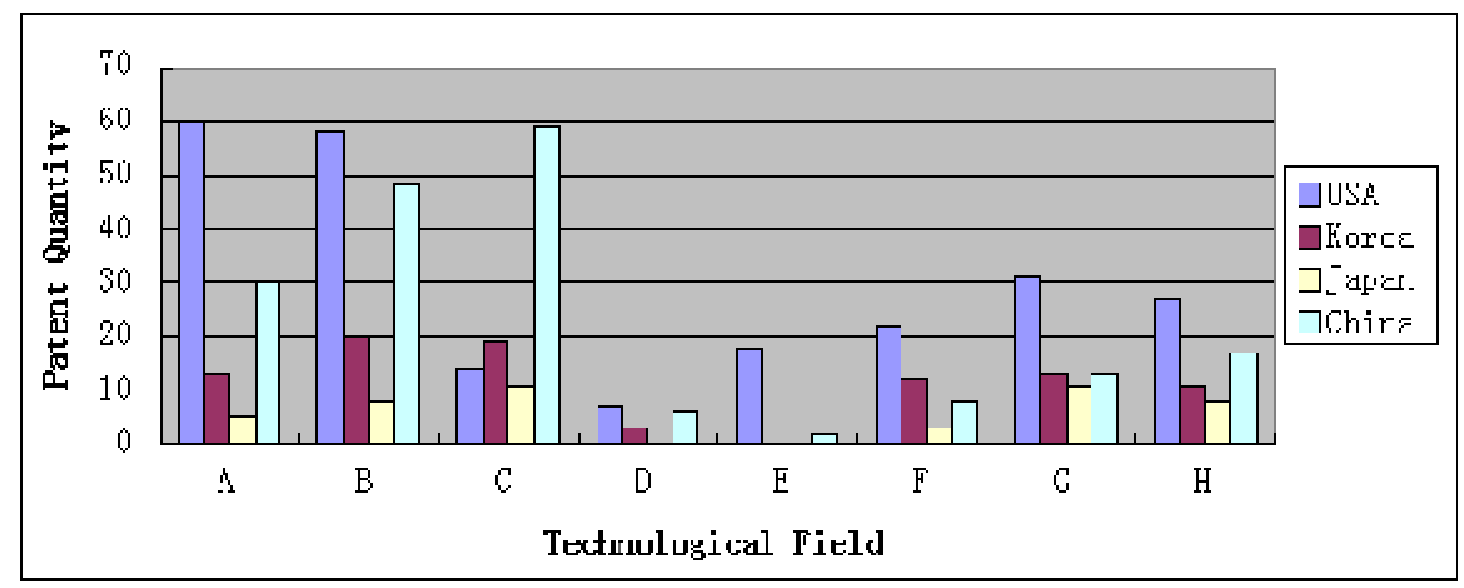

Figure 1. The distributions of foreign patents without the foreign priority in technological fields in four countries

The nationalities distribution of applicants own foreign patents without the foreign priority. Figure 2 shows the nationalities distributions of applicants own foreign patents without the foreign priority in four countries. In USA, the numbers of patents owned by applicants from Chinese Taiwan and Japan are far more than that of applicants from Germany and France. In Korea, the most of patents owned by Japanese applicants, and the number of patents owned by American is more than that of applicants from China, Germany, France and England. American applicants owned most of patents in Japan. There are a little difference in the number of patents owned by English, German, 
Korean and Chinese. In China, the number of patents owned by American applicants and Japanese is far more than that of patents owned by German, English, Korean and French.

Such result indicates that American applicants and Japanese applicants own the most of foreign patents without the foreign priority granted by four countries in that American and Japanese are keen on the patent international application at that time. In other words, the number of foreign patents with the foreign priority own by American and Japanese are more than that of foreign patents with the foreign priority own by other countries.

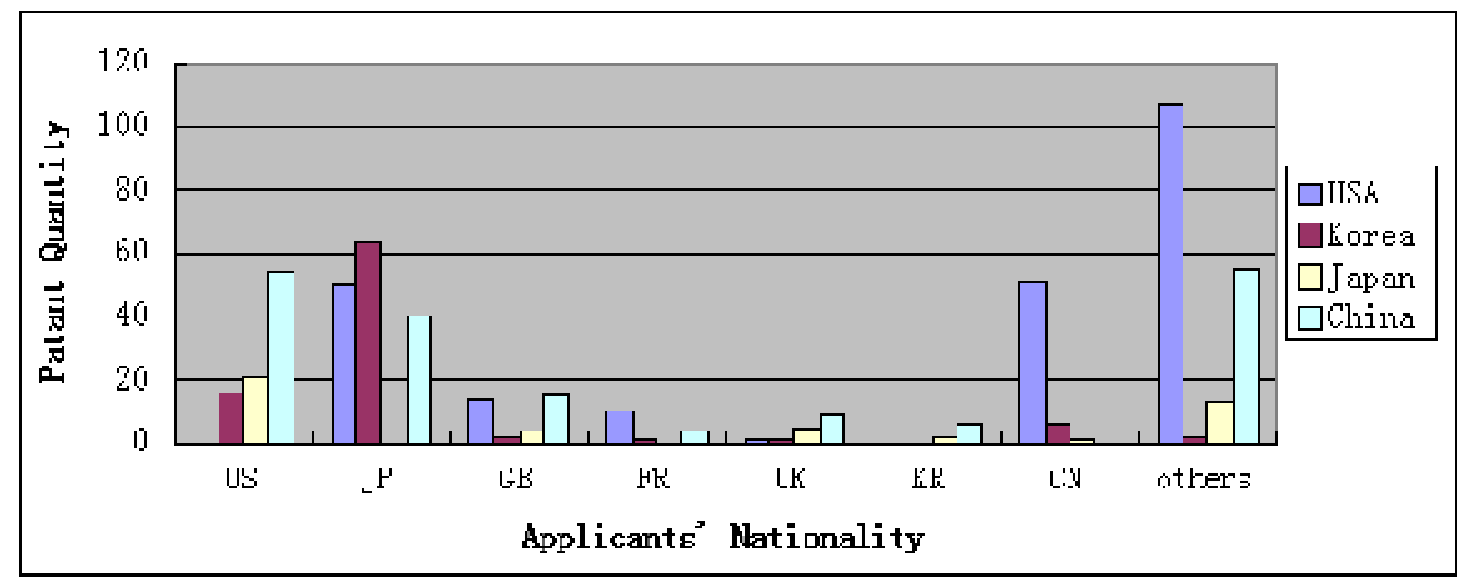

Figure 2. Comparison of the nationalities distributions of applicants own foreign patents without the foreign priority in four countries.

\section{Comparative analysis of the maintenance time of foreign patents without the foreign priority}

The sample patents are classified into domestic patents or foreign patents with the foreign priority and domestic or foreign patents without foreign priority. Foreign patents without the foreign priority are closely related with foreign patents with foreign priority, domestic patents without the foreign priority and total patent without the foreign priority. Table 2 shows the characteristic of maintenance times for foreign patents without the foreign priority.

Table 2: comparison of the average maintenance time of four kind's patents

\begin{tabular}{ccccccccccc}
\hline & $\begin{array}{c}\text { Foreign } \\
\text { patents } \\
\text { without the } \\
\text { foreign } \\
\text { priority }\end{array}$ & & Sample patents & \multicolumn{2}{c}{$\begin{array}{c}\text { Patents without } \\
\text { the foreign } \\
\text { priority }\end{array}$} & $\begin{array}{c}\text { Domestic } \\
\text { patents } \\
\text { without the } \\
\text { foreign } \\
\text { priority }\end{array}$ & $\begin{array}{c}\text { Foreign } \\
\text { patents with } \\
\text { the foreign } \\
\text { priority }\end{array}$ \\
\hline & AMT & AM & Balance & AM & Balance & AM & Balanc & AMT & Balan \\
& & T & & T & & T & e & & ce \\
US & 11.08 & 12.6 & -1.58 & 12.4 & -1.34 & 12.5 & -1.49 & 13.05 & -1.97 \\
& & 6 & & 2 & & 7 & & & \\
KR & 7.05 & 8.4 & -1.35 & 8.49 & -1.44 & 8.56 & -1.51 & 8.28 & -1.23 \\
JP & 9.2 & 9.52 & -0.32 & 9.57 & -0.37 & 9.57 & -0.37 & 8.72 & 0.48 \\
CN & 7.42 & 7.3 & 0.12 & 5.14 & 2.28 & 4.88 & 2.54 & 9.17 & -1.75 \\
\hline
\end{tabular}

Note: $\AA$ AMT: the average maintenance time.

Ç Balance=AMT of foreign patents without the foreign priority - AMT of the kind of patents.

Individual analyses of the maintenance time of foreign patents without the foreign priority granted by four countries. Figure 2 shows that average maintenance time (11.08 years) of foreign patents without the foreign priority granted by USA is smaller than that of other three kinds of patents, and their balances are more than 1 year. The balance of average maintenance time in between foreign 
patents without the foreign priority and foreign patents with the foreign priority is the largest, while the balance of average maintenance time of between foreign patents without the foreign priority and patents without the foreign priority is the smallest. In a word, it is short for the average maintenance time of foreign patents without the foreign priority granted by USA, while the average maintenance time of foreign patents with the foreign priority is longer.

The situation of the average maintenance time of foreign patents without the foreign priority granted by Korea is similar with that of foreign patents without the foreign priority granted by USA. The average maintenance time of foreign patents without the foreign priority is 7.05 years. The balance of average maintenance times in between foreign patents without the foreign priority and the patents without the foreign priority is the largest, while the balance of average maintenance times of between foreign patents without the foreign priority and foreign patents with the foreign priority is the smallest. For the patents granted by USA, the situation is similar.

In Japan, the average maintenance time of foreign patents without the foreign priority is 9.2years. The balance of average maintenance times of between foreign patents without the foreign priority and other kinds of patents (except foreign patents with the priority) is smaller than that of corresponding patents granted by USA and Korea. Especially, the maintenance time of foreign patents with the priority is the shortest. Overall, the maintenance time of all kinds of patents is close, and the maintenance time of domestic patents is longer than that of foreign patents.

The situation of average maintenance times for four type's patents granted by China is opposite with that of patents granted by Japanese. The average maintenance time of foreign patents without the foreign priority is shorter than that of foreign patents with the priority, but it is longer than that of other three kind's patent. The balance of average maintenance time of between foreign patents without the foreign priority and other kind's patents is larger. This phenomenon indicates that the average maintenance time of foreign patents is longer, while the maintenance time of domestic patents is shorter.

From the above facts, we could find that average maintenance times of foreign patents without the foreign priority granted by USA, Korea and Japan are shorter, while the average maintenance time of foreign patents without the foreign priority granted by China is longer.

Comparative analyses of the average maintenance time of foreign patents without the foreign priority granted by four countries. From figure 2, the average maintenance time of foreign patents without the foreign priority granted by USA is the longest in four countries, because of the patent annual fee system in USA. The trends of maintenance time of foreign patents without the foreign priority in USA, Japan and Korea are almost similar, meanwhile they have two differences. Firstly, the average maintenance time of foreign patents without the foreign priority granted is longer than that of foreign patents with the foreign priority by Japan; however the average maintenance time of foreign patents without the foreign priority granted by Japan are shorter than that of foreign patents with the foreign priority by USA and Korea. Secondly, the balance of between the average maintenance time of this type and the average maintenance time of other type's patents is smaller (0.37years), while this data in USA and Korea are about $1.5 y$ years. The situation of the average maintenance time of this type patents in China is different from other three countries, and it's opposite with Japan totally. What's more, the balances of between the average maintenance times of foreign patents without the foreign priority and other types patents are slight fluctuations in USA, Korea and Japan, but this balance in China vary wildly, and the range is from 0.2years to 2.54years. The average maintenance time of foreign patents without the foreign priority is shorter than that of foreign patents, which is similar with USA and Korea.

Because the maintenance time of domestic patents is relatively short, the situation of patents maintenance time in China is different from others. There are 1601 domestic patents without the foreign priority, accounting for $89.74 \%$ of patents without foreign priority. The average maintenance times of these patents are only 4.88 years, which shorten the average maintenance times of the patents without the priority directly. What's more, the total maintenance time of domestic patents also is 4.89 years. Therefore the average maintenance time of all sample patents relatively shorter. It indicates that the average ability to use patents for patentees in China is poorer than that of foreign patentees. 
So we suggest Chinese patentees should convert patents into productivity actively, rather than just take the patents as an honor.

\section{Conclusion}

Comparative research on foreign patents without the foreign priority helps us know the difference between this patents' maintenance time and other kinds of patents' well, meanwhile help us know more about the influence for the foreign priority on the patent maintenance time. From above analysis, we could find that the quantities of foreign patents without the foreign priority in USA, Korea and Japan are smaller. Most of this type patents distribute in technological field A (Agriculture), B (Performing Operations and Transporting) and C (Chemistry and Metallurgy, and the majority of applicants of this type patents are from American and Japanese. The maintenance times of foreign patents without the foreign priority granted by USA, Korea and Japan are relatively short, while the maintenance times of foreign patents without the foreign priority granted by China is relatively long.

The maintenance situations of foreign patents without the foreign priority granted by USA, Korea and Japan are almost similar, but it is different for foreign patents without the foreign priority granted by China. This phenomenon maybe relate to the unbalanced development of intellectual property in different countries. American and Japanese have stronger innovation abilities, and the awareness to protect their inventions. What's more, their well-developed international trades also encourage them to apply for the PCT patents. But in China, the innovation abilities and the awareness of intellectual property protection are relatively weak in that time. Of course, with the perfection of intellectual property system and the reinforcement of intellectual property protection awareness, the gaps of average maintenance time of foreign patents without the foreign priority China and other countries might be narrowed shorten.

\section{Acknowledgements}

This work was financially supported by the National Natural Science Foundation of China (batch number: 71373221)

\section{References}

[1] Zeebroeck N V. Patent only live twice: A patent survival analysis of the determinants of examination lags, grant decision, and renewals [R]. Working Papers CEB, 2007:10-15.

[2] Scotchmer, S. On the Optimality of the Patent Renewal System [J]. RAND Journal of Economics, 1999,30(2):181-196.

[3] Wu Hong, Fu Xiuying, Dong Kun. Empirical analysis of the affecting factors of patent maintenance time [J]. Library and Information Service, 2013,57 (24):112-116. (in Chinese)

[4] Schankerman, M. and Pakes, A. Estimates of the Value of Patent Right in European Countries during the Post-1950 Period [J]. The Economic Journal, 1986, 96(12):1052-1076.

[5] Zhu Xuezhong, Qiao Yongzhong, Wan Xiaoli. Empirical research on the patent quality basis on the maintenance time [J]. Management World, 2009,(1):174-175. (in Chinese)

[ 6 ] Eike Ullmann. The Priority Right in Patent Law- Use and Misuse? [DB]. http://link.springer.com/chapter/10.1007/978-3-540-88743-0_7.Patents and Technological Progress in a Globalized World, 2009/2015.1.16.

[7] Du Juan. Problem of the nature and transfer of the foreign priority of patents [J]. Cuide to Business, 2010, (12):173-174. (in Chinese)

[8] Decision $\mathrm{T}$ 15/01 of June 17, 2004 of the Board of Appeal of the European Patent [DB]Office.http://www.epo.org/law-practice/case-law-appeals/pdf/t010015ex1.pdf, 2004/2015.5.10 